
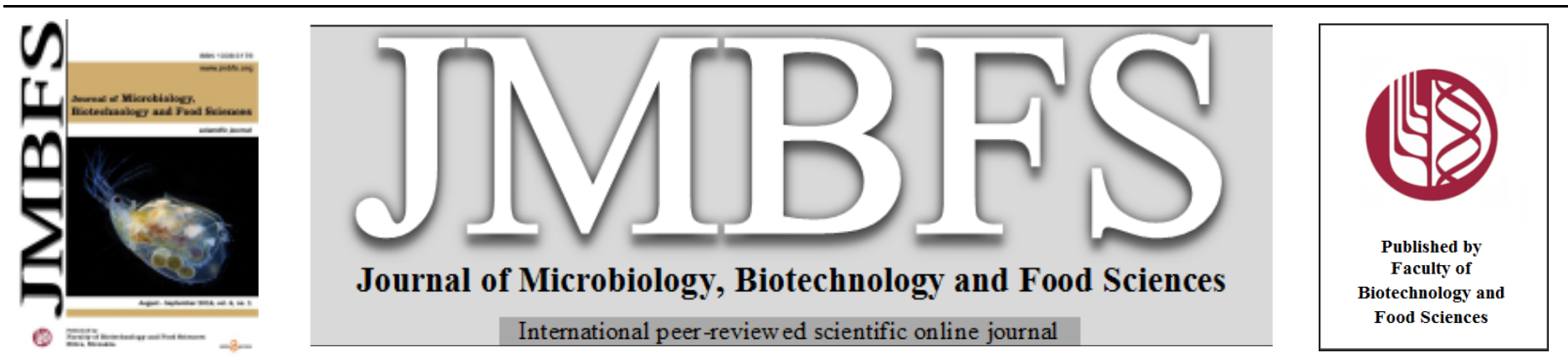

\title{
EVALUATION THE RISK OF TOXIC COMPOUNDS FORMATION IN GRAPE AND FRUIT BRANDIES
}

\author{
Dimitar Dimitrov ${ }^{*}$, Tatyana Yoncheva, Vanyo Haygarov
}

\section{Address(es):}

Institute of Viticulture and Enology, Department of Enology and Chemistry, Kala tepe 1 str., 5800, Pleven, Bulgaria, phone number: +359 885540245.

*Corresponding author: dimitar_robertov@abv.bg

doi: 10.15414/jmbfs.2016.6.1.681-684

\section{ARTICLE INFO}

Received 22. 10. 2015

Revised 17. 3. 2016

Accepted 5. 4. 2016

Published 1. 8. 2016

Regular article

open $\odot$ Access

\begin{abstract}
Study to determine the quantities of accumulating harmful to consumer health compounds in grape and plum brandies was conducted. Gas chromatographic assay of the volatile components in grape brandies founded that the amounts of methanol (compound with the highest index of danger for health) ranging from $12.44 \pm 0.03-54.40 \pm 0.10 \mathrm{mg} / 100 \mathrm{ml}$ a.a., which values are several times lower than the limits legalized in the EU Regulation - to $1000 \mathrm{mg} / 100 \mathrm{ml}$ a.a. The results for the second component which also represents a health hazard to the consumer (acetaldehyde) varied from $2.08 \pm 0.10$ to $4.17 \pm 0.04 \mathrm{mg} / 100 \mathrm{ml}$ a.a. This concentration is low and comparable with the data obtained by other researchers which established it as harmless to the consumer health. Studies on the plum brandies founded higher values of methanol $-416.00 \pm 0.12-458.02 \pm 0.10 \mathrm{mg} / 100 \mathrm{ml}$ a.a., which is understandable in view of the higher pectin levels in the plum fruit, which are precursor for the formation of methanol. The obtained results for plum brandies were within the maximum permissible levels described in Regulation №110/2008 of the European Union. The analyzes on grape and plum brandies indicated that they were safe for consumption.
\end{abstract}

Keywords: Plum brandies, grape brandies, methanol, acetaldehyde, higher alcohols

\section{INTRODUCTION}

Brandy is a traditional alcoholic drink in Bulgaria and other countries in Balkan region with a relatively high index of consumption. The lack of overall knowledge on the mechanisms of alcoholic fermentation and technological parameters in the production of brandies, leading in many cases to obtain of final product with low quality and great uncertainty with regard to health safety.

The fermentation process is usually realized in wooden, metal or plastic containers for food purposes. This microbiological process is usually performed without the addition of cultivated yeasts, and rely of spontaneous fermentation induced by wild yeasts that are normal present microflora on the fruit parts. In many cases the distillation process is carried out in copper stills into an open fire. It is claimed that this type of distillation does not allow the controlling constant temperature, which negatively affects the proper realization of the process (Coldea et al., 2011; Tesevic et al., 2009; Kostik et al., 2014; Pomahaci et al., 1892).

Storage and aging of this type alcoholic beverages are usually realized in oak barrels for a period at least 2-3 months, which ensures the formation of a specific aroma and bouquet and golden yellow color (Stanimirovic and Stanimirovic, 1982). For the flavor and aroma of the fruit and grape brandies essential importance have many volatile compounds formed during the fermentation by metabolic activity of the yeasts cultures (Sacharomyces cerevisiae) and during storage and aging of the beverages. Some of these compounds - acetaldehyde, methanol and some higher alcohols can have adverse toxicological effects on the human body after consumption of beverages containing them in high concentrations (Kostik et al., 2014; Coldea et al., 2013; Obosamiro, 2013). Because of this fact they are subject to regulation by the European and local legislations.

Methanol is a compound with very high degree of health hazard to the consumer. It is a naturally occurring component in brandies, especially these produced from rotten fruits with a high concentration of pectin (Coldea et al., 2011). The mechanism of methanol formation is connected with the action of the enzyme pectin-methyl-esterase, which contain in greater concentration in the stone fruits. Under the action of this enzyme occurs demethylation of pectin and release methanol together with pectinic acid and pectol (Coldea et al., 2011; Lukic et al., 2011). In general, the mechanism for action of pectolytic enzymes follows the scheme: initial decomposition of insoluble (protopectin) to soluble pectin under the action of the enzyme protopectinase; subsequent degradation of the resulting soluble pectin to the polygalacturonic acid and methanol under the action of the enzyme pectinesterase; subsequent decomposition of polygalacturonic acid to galacturonic acid by the action of polygalactouronase (Marinov, 2005). The consumption of beverages with concentrations of methanol exceeding permissible levels can lead to permanent blindness, surrogate toxicity (Paine and Davan, 2001), and after consumption of larger quantities - to the death of the consumer, has already been reported (Lachenmeier et al., 2007). The toxic mechanism in the ingestion of large amounts of methanol relates to the formation of formaldehyde and formic acid (cell poisons) in the body of the consumer (Skrydlewska, 2003).

Kostik et al. (2014) studied grape brandies obtained after distillation of grape juice, after distillation of grape mash and after distillation of wine. They founded a wide variation of the methanol content in the three test variants. The concentration of methanol in their study ranges from 3.5 to $883 \mathrm{mg} / 100 \mathrm{ml}$ a.a.

Because of the high index of danger from brandy consumption (produced at improper realized production technology), permissible concentrations of methanol are regulated by European legislation. The maximum permissible amount of methanol in grape and fruit brandies is assessed by the European Commission of $10 \mathrm{~g} / \mathrm{l}$ of pure ethanol, which is equivalent to $1000 \mathrm{mg} / 100 \mathrm{ml}$ absolute alcohol (EEC Council Regulation №110, 2008).

Acetaldehyde is produced by the dehydrogenation of ethanol and may occur during fermentation, as a minor component (Coldea et al., 2011). Acetaldehyde is a highly toxic metabolite. It increased in the aging period of brandies, due to the chemical oxidation of ethanol and the subsequent oxidation of the resulting acetaldehyde to form acetic acid (Silva and Malcata, 1998; Obosamiro, 2013). Consumed in high concentrations it can result in various harmful effects on the body - dizziness, vomiting and nausea. European legislation does not provide permissible limits of acetaldehyde concentrations, which makes its quantification extremely important. Apostoloupolou et al. (2005) founded the range for the content of this component in brandies from $1.3-59.7 \mathrm{mg} / 100 \mathrm{ml}$ a.a. 
Ethyl acetate is an ester of ethanol and acetic acid. Its high concentrations in alcoholic drinks represent an indicator for incorrectly performed alcoholic fermentation and prolonged storage period (Tesevic et al., 2009). Established levels of this component in a variety of fruit brandies were in range - 7.66 $692.1 \mathrm{mg} / 100 \mathrm{ml}$ a.a. (Apostoloupolou et al., 2005).

The higher alcohols are final products of amino acid metabolism of the yeasts. Their quantities in alcoholic beverages are highly dependent of the concentrations of amino acids in the fruit raw material which are subject to a fermentation process. The main property of the higher alcohols is their strong influence on the aroma and taste of the drink (Bonte, 1987), giving the drink fruity notes.

The aim of this study was to identify and evaluate a quantitative accumulation of harmful for the health of the consumer compounds in grape and plum brandies.

\section{MATERIAL AND METHODS}

\section{Origin of tested samples}

Five samples for analysis were provided - three of them were grape brandies and two of them were plum brandies. All five grape and fruit brandies were produced in the town of Pleven, Bulgaria.

\section{Analysis of the volatiles}

To determine the major volatile compounds, brandies were directly injected into the gas chromatograph Varian Model 3900 with a capillary column VF-Wax MS (30 m, 0,25 mm ID, DF $=0,25 \mu \mathrm{m}$ ), equipped with a flame ionization detector (FID). The carrier gas was He. Hydrogen was supplied to the chromatograph via a hydrogen generator (model Parker Chroma Gas; Gas Generator 9200). The amount of injected material into the chromatograph was $2 \mu$. The injection was manual by microsyringe with calibrated scale (Hamilton Co.) with a maximum capacity of $10 \mu \mathrm{l}$.

The parameters of the gas chromatographic determination were: injector temperature $-210{ }^{\circ} \mathrm{C}$, initial oven temperature $-40{ }^{\circ} \mathrm{C} /$ retention- $2 \mathrm{~min}$, rise to $200{ }^{\circ} \mathrm{C}$ with $15{ }^{\circ} \mathrm{C} / \mathrm{min}$ for $17,67 \mathrm{~min}$. Total time of chromatography analysis $19,67 \mathrm{~min}$; temperature of the detector $-250^{\circ} \mathrm{C}$.

The major volatile compounds identified by GC-FID were: acetaldehyde, ethyl acetate, methanol, 1-propanol, 2-methyl-1-propanol, 1-butanol, 2-methyl-1butanol, 2-butanol, 3-methyl-butanol, 1-pentanol, 1-hexanol, 1-heptanol. The compounds were identified by comparison of their retention times with those of authentic pure compounds. Solution of pure compounds with known concentrations was injected in an amount of $2 \mu$. The detected retention times of injected pure compounds are presented in Table 1.

Table 1 The retention times of pure compounds after injection of the standard solution

\begin{tabular}{lcc}
\hline № & Volatile compound & Retention time $(\mathbf{R t})$ \\
\hline 1 & acetaldehyde & $2.312 \pm 0.011$ \\
\hline 2 & ethyl acetate & $3.600 \pm 0.013$ \\
\hline 3 & methanol & $3.709 \pm 0.009$ \\
\hline 4 & 1-propanol & $5.001 \pm 0.010$ \\
\hline 5 & 2-methyl-1-propanol & $5.171 \pm 0.012$ \\
\hline 6 & 1-butanol & $5.793 \pm 0.011$ \\
\hline 7 & 2-methyl-1-butanol & $6.433 \pm 0.008$ \\
\hline 8 & 2-butanol & $7.011 \pm 0.010$ \\
\hline 9 & 3-methyl-butanol & $7.416 \pm 0.011$ \\
\hline 10 & 1-pentanol & $7.697 \pm 0.013$ \\
\hline 11 & 1-hexanol & $8.352 \pm 0.008$ \\
\hline 12 & 1-heptanol & $8.916 \pm 0.010$ \\
\hline 13 & 1-octanol & $9.252 \pm 0.006$ \\
\hline
\end{tabular}

The quantitative evaluation of each of the tested compounds in brandies was carried out by the method of the internal standard. As an internal standard was used 1-octanol.

\section{Chemicals and reagents}

Chemically pure substances were used: acetaldehyde, ethyl acetate, methanol, 1butanol, 2-methyl-1-butanol, 2-butanol, 3-methyl-butanol, 1-propanol, 2-methyl1-propanol, 1-pentanol , 1-hexanol, 1-heptanol, 1-octanol (internal standard). All of them with a purity exceeding $99 \%$. They were purchased from Fluka (Sigma Aldrich Co.).

\section{Statistical analysis}

The statistical analysis of the data is carried out by determining the standard deviation (SD), with triple repetition of the analyses. It is performed with the Excel 2007 software application of the Microsoft Office 2007 suite (Microsoft Corporation, USA).

\section{RESULTS AND DISCUSSION}

The ethanol content (vol. \%) of the tested samples is presented in Table 2. In grape brandies it was in range of 40.20 vol. $\%$ to 45.80 vol. \%; in plum brandies it was in range of $48.00 \mathrm{vol} . \%$ to $51.7 \mathrm{vol}$. \% . These indicators shall be brought to standard alcoholic degrees regulated by the Bulgarian and European legislation.

Table 2 Identified concentrations of ethanol in grape and fruit brandies

\begin{tabular}{lc}
\hline Brandy samples & Content of ethanol, vol. \% \\
\hline Grape brandy 1 & 45.80 \\
\hline Grape brandy 2 & 45.70 \\
\hline Grape brandy 3 & 40.20 \\
\hline Plum brandy 1 & 51.70 \\
\hline Plum brandy 2 & 48.00 \\
\hline
\end{tabular}

On the base of injection of standard solution consist pure substances were found the components of tested brandies by the established retention times. The chromatogram of standard solution is shown in Figure 1.

After injection of the three samples grape brandies, on the base of added internal standard to each, concentration of the searched components was identified. The data of the available identified main volatile components in grape brandies are presented in Table 3.

Table 3 Concentrations of identified by GC-FID compounds in grape brandies

\begin{tabular}{|c|c|c|c|}
\hline \multirow[t]{2}{*}{ Compounds } & \multicolumn{3}{|c|}{$\begin{array}{c}\begin{array}{c}\text { Concentrations of identified volatile compounds, } \\
\text { mg/100ml a.a. }\end{array} \\
\end{array}$} \\
\hline & Grape brandy 1 & Grape brandy 2 & Grape brandy 3 \\
\hline acetaldehyde & $2.08 \pm 0.10$ & $5.34 \pm 0.12$ & $4.17 \pm 0.04$ \\
\hline ethil acetate & $11.25 \pm 0.05$ & $4.78 \pm 0.05$ & $4.56 \pm 0.08$ \\
\hline methanol & $12.44 \pm 0.03$ & $22.86 \pm 0.11$ & $54.40 \pm 0.10$ \\
\hline $\begin{array}{l}\text { 2-methyl-1- } \\
\text { propanol }\end{array}$ & $3.19 \pm 0.09$ & ND & $4.80 \pm 0.12$ \\
\hline 1-butanol & $21.76 \pm 0.10$ & $7.17 \pm 0.05$ & $5.93 \pm 0.13$ \\
\hline $\begin{array}{l}\text { 2-methyl-1- } \\
\text { butanol }\end{array}$ & ND & ND & $1.79 \pm 0.07$ \\
\hline 2-butanol & $260.75 \pm 0.15$ & $149.23 \pm 0.12$ & $59.79 \pm 0.02$ \\
\hline 1-hexanol & ND & ND & $1.51 \pm 0.03$ \\
\hline 1-heptanol & $0.841 \pm 0.12$ & ND & ND \\
\hline
\end{tabular}

The quantities of methanol in grape brandy samples varied from $12.44 \pm 0.03$ $\mathrm{mg} / 100 \mathrm{ml}$ a.a. to $54.40 \pm 0.04 \mathrm{mg} / 100 \mathrm{ml}$ a.a. The formation of methanol in grape brandy was less pronounced, because pectin concentrations in fruits of grape are lower, as compared for example with stone fruits. When the distillation was performed properly the levels of methanol resulted in minor concentrations which not affect human health after consuming of alcoholic beverages. The highest concentration of methanol in our study was found in grape brandy $3-54.40 \pm 0.10$ $\mathrm{mg} / 100 \mathrm{ml}$ a.a. Our results were in correlation with the data of Kostik $\boldsymbol{e t}$ al. (2004).

All established methanol concentrations in this study meet the requirements of Regulation №110 of the EU, 2008 which enshrines a maximum legal limit of methanol content $-1000 \mathrm{mg} / 100 \mathrm{ml}$ a.a. Our research established significantly lower methanol content than the maximum limit. This is clear indicator that the procedures for the production of grape brandies were conducted accurately and correctly.

Acetaldehyde is the second dangerous component, which in high concentrations can reflect negatively on the consumer health status. The amount of acetaldehyde in the studied grape samples ranged from $2.08 \pm 0.19 \mathrm{mg} / 100 \mathrm{ml}$ a.a. to $5.34 \pm 0.12$ $\mathrm{mg} / 100 \mathrm{ml}$ a.a. The obtained data were correlated with the results of Apostoloupolou et al. (2005). The obtained results for the concentration of acetaldehyde were an indication of properly conducted fermentation process. The 
formed acetaldehyde in grape brandies does not represent a danger for the consumer health.

Ethyl acetate has an important effect on the formation of taste. It gives fruity notes of brandies. However, this positive effect is achieved when concentrations of ethyl acetate in the product are low. The higher levels of this ester leads to the formation of unacceptable taste. In the studied grape brandies low amounts ethyl acetate were established. It varied from $4.56 \pm 0.08 \mathrm{mg} / 100 \mathrm{ml}$ a.a. to $11.25 \pm 0.05$ $\mathrm{mg} / 100 \mathrm{ml}$ a.a. The established content of this ester in Bulgarian grape brandies was in correlation with the data of Apostolopolou et al. (2005).

Higher alcohols are also important for the formation and expression of the product taste characteristics. The highest concentration in the tested fraction of higher alcohols was established for 2-butanol. It varied between $59.79 \pm 0.02$ $\mathrm{mg} / 100 \mathrm{ml}$ a.a. and $260.75 \pm 0.15 \mathrm{mg} / 100 \mathrm{ml}$ a.a. The data were in correlation with studies of Apostoloupolou et al. (2005). In the brandy sample 1 we established a slightly higher concentration of 2-butanol, which is likely due to the use of raw material with higher content of amino acids which are a precursor for the formation of higher alcohols.

The reported values for the presence of 1-butanol ranged from $5.93 \pm 0.13$ $21.76 \pm 0.10 \mathrm{mg} / 100 \mathrm{ml}$ a.a. and also correlated with the results of other researchers (Apostoloupolou et al., 2005; Claus and Bergland, 2005; Cortes et al., 2010).

The data for the second type of studied brandies which made from plums are presented in Table 4.

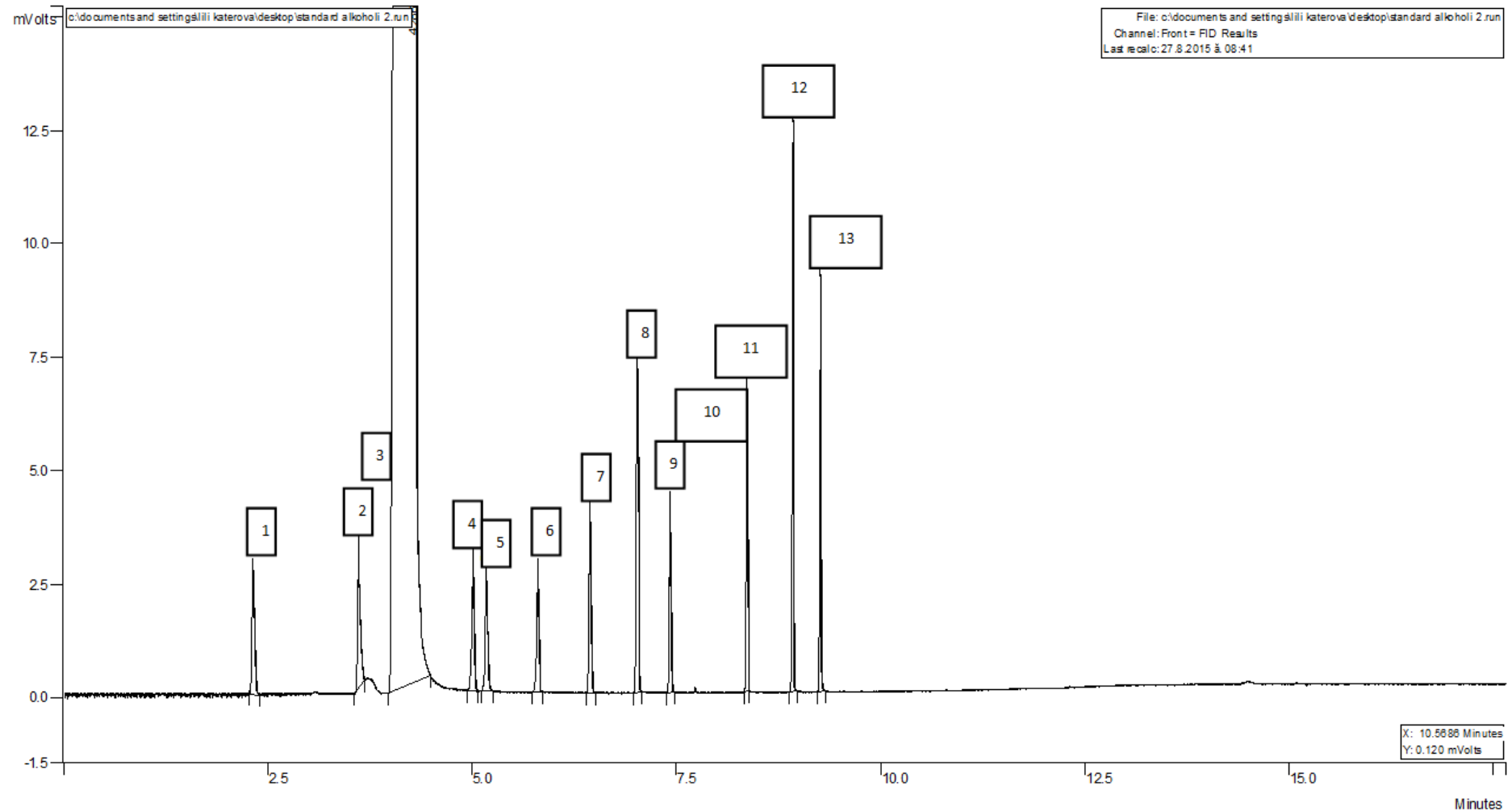

Figure 1 Chromatogram of identified pure compounds in standard solution (1- Acetaldehyde; 2- Ethyl acetate; 3- Methanol; 4- 1-propanol; 5- 2-methyl-1-propanol; 61-butanol; 7- 2-methyl-1-butanol; 8- 2-butanol; 9- 3-methyl-butanol; 10- 1-pentanol; 11- 1-hexanol; 12- 1-heptanol; 13- 1-octanol)

Table 4 Concentrations of identified by GC-FID compounds in plum brandies

\begin{tabular}{lcc}
\hline Compounds & $\begin{array}{c}\text { Concentrations of identified volatile compounds, } \\
\text { mg/100ml a.a. }\end{array}$ \\
\cline { 2 - 3 } & Plum brandy 1 & Plum brandy 2 \\
\hline acetaldehyde & $2.36 \pm 0.05$ & $1.51 \pm 0.12$ \\
\hline ethil acetate & $1.54 \pm 0.11$ & $1.32 \pm 0.04$ \\
\hline methanol & $458.02 \pm 0.10$ & $416.00 \pm 0.12$ \\
\hline 2-methyl-1-propanol & $2.44 \pm 0.05$ & $\mathrm{ND}$ \\
\hline 1-butanol & $3.89 \pm 0.12$ & $2.11 \pm 0.02$ \\
\hline 2-butanol & $76.63 \pm 0.13$ & $2.61 \pm 0.08$ \\
\hline
\end{tabular}

*ND-Not detected

The obtained results for the primary toxic compound - methanol in plum brandies showed a trend of higher quantities compared to grape brandies. The resulted concentrations of methanol in plum brandies varied from $416.00 \pm 0.12$ to $458.02 \pm 0.10 \mathrm{mg} / 100 \mathrm{ml}$ a.a. This results are explained by the fact that the plums used as raw material for the production of brandy are a rich source of pectin, which is a precursor for the production of methanol in the final product. Despite having found a higher content of methanol in plum brandies than that of grape brandies, the concentration of this component is within the legal limit of 1000 $\mathrm{mg} / 100 \mathrm{ml}$ a.a., approved by the European Union (Reg. 110/2008). This makes the product safe for consumption with acceptable levels of methanol.

\section{CONCLUSION}

The conducted research on the assessment the risk of toxic compounds formation in fruit and grape brandies founded concentrations of harmful components that are within permitted concentration levels regulated in European legislation. Moreover, the obtained results correlated with the data of other researchers.

In plum brandies higher levels of methanol were obtained, which is understandable in view of the higher content of pectin in the fruit raw material used for brandy production, but these higher levels are within concentrations of legalized maximum limits of EU.

The obtained results of this research are evidence for properly perform production process of studied grape and fruit brandies, making them safe for consumption.

\section{REFERENCES}

APOSTOLOPOULOU, A.A., FLOUROS, A.I., DEMERTZIS, P.G., AKRIDADEMERTZI, K. 2005. Differences in concentration of principal volatile constituents in traditional Greek distillates. Food Control, 16:157164.http://dx.doi.org/10.1016/j.foodcont.2004.01.005

BONTE, W. 1987. Begleitstoffe alkoholischer Getranke: Biogenese, Vorkommen, Pharmakologie, Physiologie und Begutachtung. Verlag Max Schmidt - Romhild, Lubeck. 
CLAUS, M., BERGLUND, K. 2005. Fruit brandy production by batch column distillation with reflux. Journal of Food Process Engeneering, 28(1):53-67. http://dx.doi.org/10.1111/j.1745-4530.2005.00377.x

COLDEA, T., SOCACIN, C., DAN VODNAR, M. 2011. Gas-Chromatographic analysis of major volatile compounds found in traditional fruit brandies from Transylvania, Romania. Not Bot Horti Agrobo, 39(2):109-116.

COLDEA, T., SOCACIN, C., FETEA, F., RANGA, F., POP, R., FLOREA, M. 2013. Rapid quantitative analysis of ethanol and prediction of methanol content in traditional fruit brandies from Romania using FTIR Spectroscopy and Chromometrics. Not Bot Horti Agrobo, 41(1): 143-149.

CORTES S., SALGADO, J.M., RODRIGUEZ, N. DOMINGUEZ, J.M. 2010. The storage of grape marc: Limiting factor in the quality of the distillate. Food Control, 21(11):1545-1549. http://dx.doi.org/10.1016/j.foodcont.2010.04.029 KOSTIK, V., GJORGESKA, B., ANGELOVSKA, B., KOVACHEVSKA, I. 2014. Determination of some volatile compounds in fruit spirits produced from grapes (Vitis vinifera L.) and plums (Prunus domestica L.) cultivars. Science Journal of Analytical Chemistry, 2(4):4146. http://dx.doi.org/10.11648/j.sjac.20140204.12

LACHENMEIER, D.W., REHM, J., GMEL, G. 2007. Surrogate alcohol: what do we know and where do we go. Alcohol. Clin. Exp. Res., 31:16131624. http://dx.doi.org/10.1111/j.1530-0277.2007.00474.x

LUKIC, I., MILICEVIC, B., BANOVIC, M., TOMAS, S., RADEKA, S., PERSURIC, Đ. 2011. Secondary aroma compounds in fresh grape marc brandies as a result of variety and corresponding production technology. Food Technol. Biotechnol., 49(2):214-227.

MARINOV, M. 2005. Technology of alcoholic beverages and spirit. Academic Press of Univeristy of food technologies, Plovdiv, Bulgaria. ISSN: 0477-0250.

OBOSAMIRO, T. 2013. Analysis of some contaminants commonly found in alcoholic beverages. American-Eurasion journal of scientific research, 8(1):5356.

PAINE, A., DAVAN, A.D. 2001. Defining a tolerable concentration of methanol in alcoholic drinks Hum Exp Toxicol, 20(11):563568. http://dx.doi.org/10.1191/096032701718620864

POMOHACI, N. CIOLTEAN, I. VISAN, L., RADOI, F. 1892. Tuica and natural brandies. Ed. Ceres. Bucharest, Clerk Maxwell, A Treatise on Electricity and Magnetism, 3rd ed., vol. 2. Oxford: Clarendon, 1892, pp.68-73.

REGULATION (EU) No 110/2008 OF THE EUROPEAN PARLIAMENT AND OF THE COUNCIL of 15 January 2008 on the definition, description, presentation, labelling and the protection of geographical indications of spirit drinks and repealing Council Regulation (EEC) No 1576/89.

SILVA, M.L., MALCATA, F.X. 1998. Relationships between storage conditions of grape pomace and volatile composition of spirits obtained there from. American journal of enology and viticulture, 49(1):56-64.

SKRZYDLEWSKA, E. 2003. Toxicological and metabolic consequences of methanol poisoning. Toxicol Mech Methods, 13(4):277-293.

http://dx.doi.org/10.1080/713857189

STANIMIROVIC, S., STANIMIROVIC, D., 1982. "Bromatologija”, Zavod za Udzbenike i Nastavna Sredstva, Beograd, SFRJ, 1982.

TESEVIC, V, NIIKICEVIC, N, MILOSAVLJEVIC S, BAJIC, D, VAJS, V, VUCKOVIC, I, VUJISIC, L, ĐORDEVIC, I, STANKOVIC, M, VELICKOVIC, M. 2009. Characterization of volatile compounds of "Drenja", an alcoholic beverage obtained from the fruits of cornelian cherry. J. Serb. Chem. Soc., 74(2):117-128. http://dx.doi.org/10.2298/jsc0902117t 